\title{
Reflection of XI-XII century Turkic ehtnographism in the dialects of the modern Turk and
} Azerbaijani languages

\author{
Shabnam Hasanli-Garibova \\ Institute of Linguistic, \\ Azerbaijan National Academy of Sciences \\ shabnam.hasanli@yahoo.com
}

DOI:10.5901/mjss.2014.v5n22p310

\begin{abstract}
Language is the historical memory of a nation. The information that various historical-lexical layers of the language involve, indicates the past and the present, living style, the society and its layers which it shapes. One of these lexical layers is dialects. The fact of keeping features and characteristics of words in the process of turning to dialects while transferring from active dictionary to the passive one, make dialects the main source of both historical and modern literal language. Each dialect inculcates its conservatism and specific language features to new words. This tendency leads to the existence of the properties which are standardized or gradually lost, and also the properties that existed historically. The main role of dialects in historical development of the language emerges in the process of exploring ethnographic words. We can get precise information relating to XI-XII centuries' Turkic ethnographisms using dialects in contemporary languages. Besides saving historical meaning of words, in dialects, it is also observed creation of additional meanings. The word "ayak" used in the meaning of pot by XI-XII centuries' Turks, is noted using $\mathrm{a}^{\circ} \mathrm{ya}{ }^{\circ} \mathrm{k}$ phonetic composition as bowl, glass in Uzbek language, in khami accent of Uygur language it is used as "wooden cup". In modern accents of Turkic language we can come across this word in both its meaning used in XI century, and also semantic version of Uzbek language. While using as "pan or basin" in the suburbs of Konya, Afyon provinces, it is also used as "bowl" in Istanbul-Yeniköy, in some villages of Tokat and Sivas "ayak" means "tea cup". In these accents "ayak" does not earn only ambiguity, but also homonymic. In the Compilation Dictionary of Turkic language 7 homonyms of "ayak" is accentuated. At the same time, the word of "ayakçu" which are used in meanings of copper basin in Gumushane region, is also derived from "ayak". According to V. Aslanov, "ayak" were massively used in Azerbaijani language until the end of XVII century, then was oppressed by Iranian synonyms and entered to the passive glossary of the language. Not all the XI-XII centuries' ethnographisms were survived in contemporary dialects. Some words continue existence approximate similarity of their meanings as a part of other words or phrases. For example, "agı" which is mentioned by Kashgari as "decorated silk cloth" is currently not used in its initial meaning. Based on the facts that in some villages of Afyon, Eskisehir and Ankara provinces the word of "ağı çalık" defines the name of the trousers that women wear, or "agılı" means one of the cotton sorts in Afyon, we can come to this conclusion that all these words were formed on the semantic area of "agı". Consequently, in spite of the fact that ethnographism reflect so much ancient language layers, they continue their existence in dialects and they turn to the proof the historicity of the language and its dialects.
\end{abstract}

Keywords: Dialects, Turkic languages, Etnographism, Words, semantic development

\section{Introduction}

Dialect is a limited territorial form of language.In other word, dialect is a form of communication, standing against literary language . Dialect is linguistic difference, characterized by a single language system. Historical-linguistic, socio-cultural and ethnic factors are the main factors for the formation of dialects.

Words can describe different historical-lexical periods of a language. The words reflect the way of life, the society in which they are used. It is surely that all these factors can't be reflected only in the literary level of a language. Because a literary language is a language which is formed according to a lot of norms and reflects the words used only by a part of a nation. As the literary language gradually renews itself a part of the literary language becomes archaically in the process of the development. While investigating the history of the literary language we face some obstacles which prevent the process of studying. The insufficient written sources, the limited usage of the meaning of the words in these sources are these kinds of difficulties. And dialects are the first sources which are referred to in such cases. "It's interesting that some simple or derivative words that have become archaic in the literary language are met in the dialects. While passing into the passive 
vocabulary of a language words keep similar features and characteristic signs. This fact makes dialects the main source of both historical and modern literary languages. As E.Azizov noted:

«In relation to the development of the society and the language some words enter the lexicology of the dialects, later on some of which keep efficiency while some are forgotten and aren't used at all. But lexicology of the dialects are more conservative when comparing it with the literary one. Words belonged to the ancient times of the language are kept in the dialects much more." (E.Azizov, 1995)

Some words showing the existence of the dialects and the period of the dialects' development form the idea of belonging these words to the same dialects. R. Gasimova also considering these ideas right notes:

"That is why we think the idea of belonging the words which were used in the ancient Turk monuments and which exist in the dialects to the very dialects but are in the passive vocabulary of the language right." (R.Gasimova, 2010)

But this idea has only unilateral character. Because while words pass from the dialects into a literary language the opposite process happens as a lot of words pass from a literary language into dialects.

Taking into consideration all these features of the dialects A.Damirchizadeh noted:

"As it is known, dialects preserve the traces, features of the tribes before the national language had been formed or after a national language was formed it became a branch of a national language. It keeps the features of a language which was defeated in the crossing and this language is kept as a language trace during some historical periods."

That is why it is important to compare written materials with materials of the dialects while investigating the history of any language, especially when some features found in the written sources of some periods are studied. Besides it, while some words, grammatical features, sounds, phonetical events which are not found in the modern national language while they or their traces can be met in the dialects.

\section{Etnographisms in modern dialects}

The main role of the dialects appears during investigating of the ethnographic words. It is connected with the reflection of ethnographic lexicology in the dialects. Detailed information of the ethnography of the XI-XII centuries can be achieved while referring to the dialects of the modern languages. Because not only the historical meaning of the words are kept in the dialects, but also the deriving of the additional meaning from them(from the dialects) are observed. For example, "ayran" given as a kind of soft drink in Mahmood Kashgarly's dictionary " Divan- luğat-it-türk", a XI century monument, preserves its historical meaning. However in Sivas, Tokat, Balikesir, Mugla, Aydin, Denizli dialects it means a painting substance or a liquid used in agriculture.

A word "ayaq" which means "qab-qacaq/ dishes" in the language of the XI-XII centuries Turks was noted as "piyalə/qədəh" in the Uzbek language in the "ayak" phonetical structure, "taxta fincan/a wooden cup" in Khamy dialect of the Uygur language. In the dialects of the modern Turkic languages this word can be met in the both meanings - in the meaning which was used in the XI century and in the meaning which was used in the Uzbek language. "ayak" used in the meaning tas/ around Afyon, Konya means "qədəh" in Istanbul. Yenikoy "çaystəkanı" in some villages of Tokat and Sivas. "ayak" gained not only polisemantical but also omonymy in these languages. In the Dictionary of the Turk language "Derleme sözlüyü" 7 omonyms of word "ayak" were given. At the some time, "ayakci" in the meaning of "mis ləyən" used in Gumushhane district is a derivative form of "ayak". According to V.Aslanov's opinion this word was used till the end of the XVII century in the wide aspect in the Azerbaijan language but later was sıXIşdırılmaq by the synonyms of Iranian origin and included into the passive vocabulary of the language.( Aslanov V., 2003)

"Etük" which means "shoes, boots" in M.Kashgarli's dictionary exists in the dialects of the modern Turk languages but with the different meaning. "etüklük sağrı/leather which is used to make shoe" and "etükçi" (K.B.) are used in the dialectics and related to this word (etük). In the dialects of the Uzbek language the word preserved its initial variant in the phonetical structure of "əğük-əgikç etiq-ətüv-ötik-ötük".

In the form of phonetic variants "edik papuç, edik, etik" this word is used in the Turkic dialects and means "kəndli çəkməsi, uşaq ayaqqabısı, məst, yundan toxunan qısa corab, başmaq/a peasant's shoe, a child's shoe, slippers, woolen socks". The omonym of this word in Mugla district means "arıların ayğında toplanan sarı rəngli mum-a yellow substance which is gathered in the legs of the bees ". Etnographism "etükçi" having the meaning of a profession and used in "Kutadğu Bilik" as "edikci"exists in Izmir Odemish district in the meaning of a profession "pineci-a shoemaker". According to some specialists the usage of edük-etik-edik in Turk languages can be explained as the influence of the bulgar group. 
The other entographism which was used by the Turks in the XI century and still exists in the modern Turkic dialects is "al". M.Kashgarli explained this word as "silk cloth with ornaments in an orange colour". This word is used in Tukic dialects in a more different meaning. In Isparta this word is used as "toylarda bəyin boynuna salınan qırmzı dəsmal /red cloth which is tied to the bride's arm" while in Burdur and Zonguldak dialects "al" means "gəlinlərin başına örtülən uzun qırmızı örtük, duvaq/ a long red covering for bride grooms".

In "Kutadgu Bilig" "belgü" and its devivatives "belgülük, belgü, belgür, belgürt" can be met. This word is used as "nişan, əlamət /a sign" in this work and can be studied as an etnographism. Because in Turkic dialects "belgi" is used in the meaning of "nişan, hədəf/ aim" but it is used as "bəlgə" in the Azerbaijani dialects in different meaning. In Megri dialect two meanings of this word can be come across; 1 ) adaxlı qızın evinə aparılan xonça / a special present taken / sent to the fiancée; 2) boyaq üçün istifadə olunan xüsusi ağac növü/ a special kind of wood used for painting. Surely the first one of these meanings was formed by the derivative of the initial meaning and gaining of the new semantical sphere.

"Aguz" used as first milk of cow after birth in XI- XII centuries. In some of Azerbaijan dialects as Zaqatala, Qakh, Nukha, Agdash, Zerdab the word used as the same mean, and nation created a new mean of the word-«meal made from colostrum»

Not all the entograhisms of the XI-XII centuries exist in the dialects. There are some words that exist in the tərkib of some expressions or in a similar meaning. For ex., M. Kashgarli agi in the meaning of "bəzəkli ipək parça /silk ornaments cloth" and that was used in M. Kashgarli's work isn't used in the initial meaning in Azerbaijan and Turk dialects. But in some villages of Ayfon, Eskisehir, Ankara districts agicalik is used as a kind of clothes which women wear while working. In Shamkir dialect the ethnographism "ağ" means "wedge between the legs of trousers".-" Gədənin şalvarının ağı cırılıf, mərəkədə biyavır oluf'

"Agili" means a kind of cotton in Ayfon. As both the meanings are related to a dress we come into conclusion that these words were formed in the sphere of age word.

\section{Result}

As it has shown in this article, ethnographisms express the ancient period of the language they exist in the dialects and they become the evidence which shows the age of languages and dialects

\section{References}

Ozizov E.(1995). Әzizov E. Söz xəzinəsi. Söz haqqında araşdırmalar. Bakı-Maarif, 1995, s.122

Qasımova R.(2010). Qasımova R Azərbaycan dilində leksik normalaşma. Bakı, "Elm və Təhsil”, 2010, 144 s., s.56

Aslanov V. (2003). Aslanov V. Azərbaycan dilinin tarixinə dair tədqiqlər. C. II, Bakı-Elm- 2003, s. 243 